\title{
KEBIJAKAN PENERBANGAN PERINTIS DI INDONESIA: LATAR BELAKANG, TANTANGAN DAN KONTRIBUSI ${ }^{1}$
}

\author{
Yuda Benharry Tangkilisan
}

\begin{abstract}
It is a study of the Indonesian airline policy and the need of developing market for air traffic. The research is taken through the written policies of the heads of state and the ministers of communication from 1950 to the reformation era, and the interinsular flight schedules that were developed throughout the time. The primary objective of an understanding of an archipelagic conception of air communication has become the major concern of the independent republic of Indonesia since its independence in 1945. It was to maintain a strategic consideration for national purpose. The result of which, the effort of the transfer of the colonial airline system, the KLM, to the Indonesian national airline, the GIA, was successfully achieved. As the national air traffic was subsidized by thegovernment, the commercial line was partly subsidized for a national security reason to control the air traffic. Therefore, the Indonesian air transportation is to bridge the need for integrating the archipelago for effort of ethnic integration and for a national unity in a wide-spread region, despite the need for profit. However, some commercial endeavors have been initiated in the post-Soeharto era, which resulted a breakdown ofcertain airline companies. Facing the globalization, the policy would accommodate the air traffic businesses to develop their facilities for fulfilling the demand of regional welfare, but yet to increasing the supervision of the national policy on archipelagic stability.
\end{abstract}

Keywords

National sovereignty over the air transportation, national, commercial, and interinsular lines.

\section{PENDAHULUAN}

Reformasi politik pasca-era Orde Baru, yang bergulir sejak tahun 1998, mengubah berbagai ranah kehidupan masyarakat, tidak hanya di bidang politik, tetapi juga ekonomi. Keterbukaan kesempatan usaha berlangsung di berbagai sektor ekonomi, mulai dari produksi, konsumsi hingga jasa. Di sektor distribusi barang dan jasa, transportasi udara memperlihatkan keadaan yang berkembang pesat, terutama dalam pertambahan jumlah perusahaan. Di masa sebelumnya, dirgantara nasional dilayani oleh segelintir maskapai penerbangan komersial. Selain Garuda Indonesia

\footnotetext{
1 Naskah Hasil Penelitian Hibah Strategis Nasional DRPM UI 2010 untuk Penerbitan Paradigma FIB UI 2011.
} 
sebagai flag carrier, perusahaan besar lainnya antara lain adalah Merpati Nusantara Airlines (MNA), Bouraq, Mandala dan Sempati.

Di era Reformasi, dunia penerbangan memasuki masa tarif murah yang memungkinkan lebih banyak lagi kalangan masyarakat untuk menikmati angkutan yang menawarkan pelayanan cepat sampai. Strategi tersebut menimbulkan persaingan dengan moda angkutan umum lainnya, seperti kereta api dan kapal laut. Keduanya menghadapi persaingan hebat akibat perang harga, sehingga tidak jarang banyak pelayanan yang menderita kerugian besar dan lalu gulung tikar. Setidaknya, keadaan itu mengubah orientasi dan strategi perusahaan angkutan yang tersaingi tersebut. Namun, sebaliknya di antara perusahaan angkutan udara keadaan itu juga terjadi. Persaingan yang semakin menajam, menuju ke arah kondisi yang tidak sehat, memukul pangsa pasar angkutan udara yang ada. Sebagai akibatnya, sejumlah perusahaan terpaksa menutup usahanya. Contoh mutakhirnya adalah penghentian usaha perusahaan Mandala Airlines terhitung sejak pertengahan Januari 2011.

Gejala dan keadaan itu memperlihatkan kebutuhan masyarakat terhadap angkutan yang cepat dan tarif yang terjangkau. Perhubungan antartempat yang berdimensi jamak, mulai dari dinas, pendidikan hingga ekonomi memperlihatkan perkembangan masyarakat di berbagai bidang kehidupan, terutama tingkat kesejahteraan yang kian lama meningkat. Di bidang perekonomian nasional, perluasan jaringan dan frekwensi penerbangan merupakan pertanda kemajuan pembangunan. Kelancaran arus perpindahan barang dan penumpang menjadi penggerak roda perekonomian di berbagai struktur dan lapisan masyarakat serta negara.

Angkutan udara nasional memperlihatkan keadaan yang beragam. Jaringan penerbangan mengenal tingkat internasional, nasional (antar daerah) dan intra daerah. Jaringan yang disebutkan terakhir sering dikenal sebagai penerbangan perintis. Jenis penerbangan tersebut tidak jarang dipandang sebagai pelengkap angkutan udara nasional. Apalagi pelayanan penerbangan itu tidak mengenal peraihan keuntungan (gains of profit). Pelayanan itu disokong oleh subsidi yang disediakan oleh pemerintah. Walaupun demikian, perhatian terhadap pelayanan dan kiprah penerbangan perintis ini relatif belum memadai terutama apabila mempertimbangkan peranannya yang sangat penting dalam proses pembangunan nasional, yaitu bahwa sarana penerbangan itu menjadi tumpuan dalam menjalin perhubungan atau komunikasi dengan dan di daerah terpencil. Peranan itu adalah penting dalam konteks integrasi nasional. Proses integrasi menjadi tetap relevan dan signifikan untuk bangsa Indonesia yang sedemikian besar dalam segala hal untuk menjaga, melangsungkan dan melanggengkan kehidupan bernegara serta berbangsa.

Namun demikian, keadaan geografis wilayah Indonesia memperlihatkan beberapa faktor alam yang dapat menjadi kendala dalam membina kesatuan apabila tidak ditangani. Bentangan laut, sungai-sungai dan pegunungan menjadi faktor alam 
yang memisahkan antardaerah. Oleh karena itu, pembukaan dan pengembangan sarana dan prasarana perhubungan merupakan cara untuk mengatasi hambatan alam itu. Seiring dengan itu, pembinaan rasa persatuan dan cinta tanah air berkaitan erat dengan jalinan komunikasi antar warga negara di berbagai wilayah. Proses penyelenggaraan negara, seperti administrasi pemerintahan, bertumpu pada interaksi sosial dan politik secara vertikal dan horizontal. Dalam konteks ini, perhubungan memegang peranan kunci. Salah satu bentuk perhubungan itu adalah angkutan darat. Dalam perkembangan ekonomi, transportasi sebagai faktor distribusi memegang peranan penting dalam siklus produksi dan konsumsi. Arus barang dari sektor produksi hingga tiba ke tangan konsumen atau sektor konsumsi dimungkinkan oleh fungsi distribusi. Oleh karena itu, dalam pembangunan ekonomi nasional, transportasi memainkan peranan yang tidak dapat dikesampingkan. Apalagi, sebagaimana dijelaskan bahwa keadaan alam dan geografi tanah air memperlihatkan kebutuhan alat transportasi sebagai condition sin qua non, yaitu menjadi mutlak. Akibatnya, keragaman geografis itu melibatkan beragam moda transportasi, yakni darat, laut dan udara.

Demikianlah, geografi Indonesia berupa bentangan maritim mengisyaratkan peranan dan fungsi angkutan laut dalam bentuk armada perkapalan. Indonesia sebagai negara maritim memperoleh pengakuan internasional melalui kesepakatan UNCLOS (United Nations Convention on Law of Seas) yang memberikan batas wilayah dimulai dari titik sejauh 12 mil dari pulau-pulau terluar yang saling terjalin. Seraya itu, Indonesia harus membuka jalur pelayaran internasional (sea lanes), seperti di Selat Sunda, Lombok, dan Sulawesi. Namun, keadaan perkembangan angkutan laut nasional tidak dapat melayani kebutuhan transportasi seluruh daerah, termasuk di kawasan kepulauan seperti Nusa Tenggara dan Maluku. Juga angkutan darat tidak mudah melayani kebutuhan serupa di kawasan persungaian, seperti di Kalimantan, dan pegunungan di Papua.

Walaupun maritim di Indonesia diharapkan dapat mengakomodasi Dirgantara nasional memperlihatkan keadaan yang tidak jauh berbeda. Indonesia belum menguasai dan mengendalikan seluruh wilayah dirgantaranya "....karena ada sebagian wilayah udara kedaulatan Republik Indonesia yang berstatus sebagai wilayah Indonesia yang tidak memiliki kedaulatan yang lengkap dan eksklusif, yaitu wilayah udara yang berada di bawah pengaturan FIR (Flight Information Region). Di wilayah kedaulatan RI inilah seluruh pengaturan penerbangan berada di bawah otoritas Singapura. Sungguh merupakan kondisi yang sangat memprihatinkan. Ditambah lagi karena sudah berlangsung puluhan tahun, maka sering kali otoritas pengatur lalu lintas udara Singapura bertindak berlebihan (over acting) dalam mengatur pesawat Indonesia di atas wilayah Indonesia sendiri dengan mengatasnamakan keselamatan penerbangan (yang sebenarnya adalah bisnis penerbangan) di Changi Airport untuk kepentingan Singapura sendiri." (Hakim 2010: 46). Namun, melalui Undang-Undang nomor 1 Tahun 2009 tentang Penerbangan, keadaan itu berlangsung tidak lebih selama sepuluh tahun mendatang karena setelah itu 
pengaturan wilayah udara tersebut diambil alih oleh Indonesia.

Berdasarkan keadaan tersebut, peranan penerbangan perintis tampak jelas signifikansi dan relevansinya. Bersama kekuatan Angkatan Udara dan penerbangan komersial, penerbangan itu menjadi komponen dalam memelihara dan menegakan kedaulatan bangsa di udara (sky souvereignity). Pengawasan terhadap dirgantara menjadi penting untuk Indonesia sebagai negeri kepulauan yang memiliki masyarakat yang sangat majemuk, multietnik dan multikultural. Dengan demikian, pengawasan terhadap wilayah maritim yang membentang luas akan lebih efektif dilakukan melalui udara.

\title{
GAGASAN-GAGASANTENTANG PENERBANGAN NASIONAL
}

Dirgantara, seperti ujaran Presiden Pertama RI Sukarno menjadi tumpuan masa depan, menyimpan potensi dan dinamika yang signifikan dan berdampak besar dalam kehidupan dan perkembangan masyarakat serta negara. Dalam tulisan Hakim (2010: 58-59) dinyatakan bahwa “Pada tanggal 9 April 1951, Presiden Soekarno, dalam kapasitasnya sebagai Laksamana Tertinggi (...pangkat tertinggi di Angkatan Udara...) ...... mengatakan

\begin{abstract}
..... Indonesia adalah The most broken up nation in the world, dalam arti bahwa tidak ada satu tanah air di dunia ini, satu natie di dunia ini, satu Negara di dunia ini yang terdiri diri sekian banyak pulau, sekian banyak selat, sekian banyak laut dalam sebagai Tanah Air kita, nation kita, negara kita, Indonesia....Bung Karno telah menggunakan istilah national airpower sejak tahun 1951 untuk kekuatan udara yang dimaksudkan oleh beliau sebagai kegiatan bangsa di atas segala lapangan keudaraan atau total aviation activity....Republik Indonesia telah sejak tahun 1950-an melalui presidennya, mengatakan dan menyadari bahwa kekuatan udara nasional adalah satu sarana yang sangat penting bagi persatuan bangsa dari negara yang disebutkan oleh beliau sebagai The most broken up nation in the world.." Kemudian pendapat Sukarno mengatakan "Kekuatan udara nasional sebagai alat penting pemersatu bangsa yang dimiliki Indonesia saat ini berada pada posisi yang membutuhkan perhatian besar untuk dibangkitkan kembali eksistensinya. Tiada lain, kiranya sebagai salah satu alat penting pemersatu bangsa, tentu kekuatan udara menjadi sesuatu yang sangat dibutuhkan apabila kita hendak melihat bangsa ini tetap bersatu sebagai sarana utama untuk dapat maju" (Hakim 2010, 59).
\end{abstract}

Pemikiran lainnya mengenai dirgantara nasional berasal dari kalangan Angkatan Udara. Setelah pengakuan kedaulatan, wilayah udara memerlukan pengaturan dan pembenahan. Pemikiran itu timbul di tengah-tengah awal pembangunan nasional. Komodor Suryadarma, ketika menjabat sebagai Kepala Staf Angkatan Udara, menyampaikan pemikirannya tentang kekuatan udara (airpower) nasional. Menurutnya, kekuatan udara adalah kemampuan suatu bangsa untuk menggunakan udara (angkasa) sebebas-bebasnya bagi kepentingan nasional dan mencegah atau menghalangi pihak lain/asing untuk memakainya tanpa mengindahkan kedaulatan nasional $(1951,120)$. Dalam konsepsi itu tercantum tentang pembagian kerja di organisasi sipil, yakni urusan administrasi penerbangan dan pengangkutan udara sipil. Jika angkutan udara sipil 
dikelola oleh GIA, urusan administrasi penerbangan menyangkut lapangan terbang dan fasilitas pendukung penerbangan lainnya. Ia sangat tegas membatasi cakupan wewenang GIA yang hanya di bidang angkutan udara. Masih berkenaan dengan GIA, ia mengikuti kesepakatan nasionalisasi perusahaan patungan itu dalam jangka waktu 10 tahun. Selain itu, ia melemparkan gagasan tentang pembukaan maskapai penerbangan lainnya agar tidak menjadi monopoli GIA.

Gagasan yang terakhir mendapat tanggapan dan dukungan (Suradiradja 1951, 326). Landasan pikirnya adalah pemberian kesempatan kepada putera bangsa untuk ambil bagian dalam jasa transportasi udara. Merujuk kepada pengalaman pendirian Indonesian Airways, inisiatif rakyat perlu dibangkitkan dan disokong. Gambaran kepemilikannya setidaknya 70 \% untuk modal dalam negeri dan selebihnya bagi pihak penanam modal asing. Tujuannya agar meringankan tugas GIA terutama melayani penerbangan di tempat-tempat terpencil.

Menanggapi kenyataan itu, Ir. Djuanda, mantan Menteri Perhubungan menyatakan pada tahun 1953,

"Peraturan jang ada tidak sesuai dengan kedudukan kita sebagai negara jang berdaulat. Ia tidak memberi tempat kepada inisiatif Indonesia dalam lapangan penerbangan. Ia tidak memberi kebebasan dalam mendjalankan politik-penerbangan nasional... Akan tetapi kita menghendaki lebih dari itu. Kita menghendaki suatu perusahaan penerbangan jang sesungguhnya dimana pimpinan seluruhnya akan terletak pada kita dalam waktu setjepat mungkin. Atas ini kontrak itu tidak akan memberi harapan dan kedjadian2 dalam empat tahun belakangan ini memperlihatkan tanda2 tidak adanja garansi atau harapan, bahwa hal itu akan terdjadi." (Angkasa. Nopember 1953, 392).

Pandangan itu bukannya tidak berdasar karena ia menjadi ketua delegasi dalam perundingan dengan KLM Interinsulair tahun 1949. Kesepakatan yang diperoleh menyebutkan bahwa KLM bersedia menyerahkan semua asetnya kepada pemerintah Indonesia. Namun, pihak Belanda berdalih bahwa oleh karena Indonesia belum memiliki awak penerbangan dan pengalaman, untuk sementara pengelolaannya berada di bawah sebuah perusahaan patungan (Nanulaitta 1980: 118). Jelas Djuanda telah mencita-citakan agar Indonesia memiliki suatu penerbangan nasional yang mandiri.

Selanjutnya, pada peringatan hari penerbangan tanggal 9 April 1967, Jenderal TNI Soeharto selaku pejabat presiden RI menyatakan

"Banjak djasa jang telah ditjatat oleh Angkatan Udara kita dan djuga armada Penerbangan Sipil kita dalam perdjoangan bersama-sama mempertahankan dan mengisi penerbangan. Pada periode perang kemerdekaan melawan pendjadjahan dahulu, Angkatan Udara kita bahkan telah mampu menembus blockade musuh telah mampu membom sasaran-sasaran didaerah jang dikuasai musuh; jang kesemuanja itu memberi kepertjajaan kepada kemampuan diri kita sendiri dan membuka mata dunia bahwa Republik Indonesia tetap ada. Dalam melaksanakan tugas-tugas Nasional, maupun pemberontakan-pemberontakan dan pembebasan Irian Barat Angkatan Udara kita dan bahkan djuga armada udara dari "GARUDA" telah menjumbangkan peranan jang penting bagi suksesnja tugas-tugas tersebut....Kemampuan dan kekuatan Penerbangan Nasional sangat kita perlukan bagi 
pembangunan, lebih-lebih karena luasnja negara kita jang terdiri dari pulau-pulau. Dalam usaha kita bersama untuk mewudjudkan stabilisasi ekonomi, maka kemampuan penerbangan sipil kita harus diabadikan sepenuhnja, terutama dengan memberikan service jang sebaik-baiknja kepada masjarakat. ... Kita sadar sesadar-sadarnja bahwa dalam abad modern seperti sekarang ini armada penerbangan jang tangguh adalah mutlak, baik sebagai alat pertahanan keamanan maupun untuk pengembangan hubungan internasional. Oleh karena itu, kita tidak pernah akan melepaskan tjitatjita memiliki kekuatan Penerbangan Nasional jang modern dan besar dihari kemudian" (Angkasa XVII, April 1967, 70, 73).

Di balik pernyataan tersebut, tampak gagasan Presiden RI kedua itu tentang penerbangan nasional. Kebutuhan penerbangan meliputi berbagai aspek yang sangat dibutuhkan oleh pembangunan nasional. Kebutuhan itu merentang dari politik, ekonomi, pertahanan keamanan hingga hubungan internasional. Hampir 45 tahun yang lalu, ia bercita-cita agar Indonesia memiliki kekuatan penerbangan nasional yang modern.

Juga Roesmin Nurjadin sebagai Menteri/Panglima Angkatan Udara, yang kemudian menjabat sebagai Menteri Perhubungan, pada kesempatan yang sama, menyatakan sebagai berikut.

"Sering kita mendengar istilah Kekuatan Udara, Air Power dengan pendjelasan2nya versi Barat, Tetapi apa arti Air Power jang sesungguhnja harus kita telaah benar2. Sebeberapa dapat kami djelaskan disini mudah2an mendjadi bahan fikiran semua. Air Power dalam arti jang luas dan dalam adalah kemampuan suatu Negara untuk mengarahkan, memanfaatkan semua sumber 2 sosial politis, ekonomis dan teknologis untuk bisa kuat diudara dan mampu membina kelangsungan hidup perhubungan komunikasi diudara demi keselamatan Bangsa dan Negara. Kekuatan Udara Nasional tidak synonym dengan Angkatan Udara, djuga tidak berarti hanja sekedar dinilai dari banjaknja djumlah pesawat jang dimiliki. Melainkan Kekuatan Udara Nasional itu adalah penggalangan semua komponen 2 dan sumber 2 potensi jang memberikan usaha, djasa dan produksi kepada kemampuan hak hidup penerbangan. Dalam hal ini industrialisasi, kemadjuan tehnologi dan science; kemampuan ekonomi dan man power-nja, serta djalinan2 penerbangan sipil-nja merupakan komponen2 jang utama. Tjinta Udara, airmindedness adalah salah satu sumber pokok dari kegairahan membangun kekuatan udara dan bukan hanja sekedar kegairahan ingin terbang sadja. Tjinta Udara jang kami maksud adalah suatu mental dengan landasan fikiran bahwasanja media jang mempunjai nilai2 sosial, politis, ekonomis dan pertahanan. Hendaknja djangan menilai atau menganggap pesawat udara dan media udaranja itu hanja dianggap sebagai alat untuk memberikan comfort belaka. Pembinaan dari pada Tjinta Udara djangan hanja ditudjukan pada keseluruhan unsur2 jang menjangkut kegiatan penerbangan....Perhubungan udara dengan alat2 pengangkutan udara pada abad sekarang ini sudah merupakan kebutuhan hidup manusia jang vital. Djarak djauh jang pada hemat manusia biasa, tidak dapat ditjapai dalam waktu beberapa hari, sekarang sudah didjeladjahi dalam waktu hanja beberapa djam sadja. Tempat2 jang mustahil dapat didatangi manusia, maka pada abad sekarang ini bukan merupakan suatu persoalan lagi. Pendek kata hubungan udara melalui pengangkutan udara dapat mendjeladjah keseluruh pendjuru angin. Tanah air kita jang sangat luas itu terdiri dari beribu-ribu pulau. Sebagian besar dari wilajah itu belum dibangun djalan2 lalu lintas darat jang sempurna. Kebutuhan perhubungan antar daerah maupun didalam daerah itu sendiri, maka perhubungan udara memegang peranan jang penting, karena nilai2 ketjepatan, praktis dan ekonomisnja" (Angkasa XVII, April 1967, 71, 73).

Dalam perekonomian nasional, dirgantara juga memegang peranan penting terutama di bidang angkutan sebagai bagian dari siklus distribusi. Disebabkan oleh 
teknologi yang maju, penerbangan mampu menembus hambatan waktu yang menjadi kendala pada moda angkutan lainnya, yakni darat dan laut. Daya angkut penerbangan perlahan-lahan berkembang, namun karena biaya yang masih mahal terutama dalam penyediaan bahan bakar, angkutan udara memiliki keterbatasan dalam kuantitas muatan yang dapat dibawa. Melalui angkutan udara distribusi dan peredaran barang serta manusia menjadi lebih efisien dan efektif. Akhir-akhir ini, masalah biaya atau tarif telah dapat ditekan sedemikian rupa sehingga menyediakan angkutan cepat yang terjangkau serta bersaing dengan moda angkutan darat jarak jauh, seperti bus dan kereta api, dan perkapalan, termasuk kapal cepat.

Dalam perekonomian nasional, dirgantara juga memegang peranan penting terutama di bidang angkutan sebagai bagian dari siklus distribusi. Disebabkan oleh teknologi yang maju, penerbangan mampu menembus hambatan waktu yang menjadi kendala pada moda angkutan lainnya, yakni darat dan laut. Daya angkut penerbangan perlahan-lahan berkembang namun karena biaya yang masih mahal terutama dalam penyediaan bahan bakar, angkutan udara memiliki keterbatasan dalam kuantitas muatan yang dapat dibawa. Melalui angkutan udara distribusi dan peredaran barang serta manusia menjadi lebih efisien dan efektif. Akhir-akhir ini, masalah biaya atau tarif telah dapat ditekan sedemikian rupa sehingga menyediakan angkutan cepat yang terjangkau serta bersaing dengan moda angkutan darat jarak jauh, seperti bus dan kereta api, dan perkapalan, termasuk kapal cepat.

Selain sebagai faktor pendorong dalam perkembangan ekonomi, fungsi penerbangan dalam kehidupan berbangsa dan bernegara mencakup pembentukan dan peningkatan integrasi nasional. Rasa kesatuan dan persatuan, dari sudut pandang komunikasi sosial sebagai dasar dan perkembangan kebangsaan (nasionalisme), dibentuk dari interaksi sosial dan rentangan penguasaan (span of control) negara. Interaksi sosial memerlukan sarana yang efektif, dan untuk negara kepulauan seperti Indonesia adalah penerbangan. Penerbangan militer menjaga kedaulatan dan keutuhan wilayah negara, sedangkan penerbangan sipil komersial menjalin komunikasi sosial antar tempat, yang menjadi pengikat solidaritas dan identitas bangsa.

\section{AWAL PENERBANGAN NASIONAL}

Dirgantara kepulauan Indonesia mengenal pesawat udara pada masa kolonial Hindia Belanda. Penemuan alat angkut modern itu segera menyebar di awal abad ke-20, hingga ke Negeri Belanda. Dalam upaya mengukuhkan cengkraman penjajahan, negeri induk memperkenalkan alat angkutan udara itu. Pesawat-pesawat militer mengawali jejak-jejak awal penerbangan di koloni itu. Seraya perkembangan ekonomi yang semakin meningkat, kebutuhan transportasi udara timbul untuk melancarkan hubungan negeri induk dan jajahannya. Perusahaan penerbangan koloni dibentuk, yakni Koninklijk Nederlandsch Indie Luchtvaart Maatschappij(KNILM). Perusahaanini selainmenghubungkan 
negeri induk dan jajahan, juga menerbangi beberapa kota besar di koloni. Fasilitas Bandar udara Kemayoran dibangun yang juga melayani penerbangan asing lainnya. Pada masa penjajahan Hindia Belanda, masyarakat jajahan tidak memperoleh kesempatan untuk menjadi penerbang, baik militer maupun sipil kecuali sebagai navigator. Wardiman Wiryosaputro adalah putera Indonesia yang direkrut menjadi navigator pertama.

Pada masa pendudukan Jepang, jaringan penerbangan sipil terhenti. Keadaan perang tidak memungkinkan pelayanan penerbangan sipil regular. Dirgantara Indonesia diwarnai oleh pesawat-pesawat militer, baik untuk keperluan tempur maupun angkutan militer. Pada masa itu, putra Indonesia tidak memperoleh kesempatan untuk menjadi awak penerbangan. Namun ketika Jepang menyerah kepada Sekutu, menyusul penjatuhan bom atom di Hiroshima dan Nagasaki pada 6 dan 9 Agustus 1945, dan Proklamasi Kemerdekaan dikumandangkan, pesawat-pesawat Jepang segera diambilalih. Segera prajurit Angkatan udara belajar menerbangkan pesawat-pesawat itu. Adisutjipto berhasil penerbang pertama yang menerbangi angkasa negeri yang baru merdeka dengan pesawat tempur Jepang jenis churen (chureng). Walaupun terbatas, kekuatan udara Republik Indonesia mulai berkembang untuk mengimbangi angkatan udara Kerajaan Belanda.

Penerbangan sipil nasional diawali dengan gagasan untuk menyediakan sebuah pesawat kenegaraan atau kepresidenan. Walaupun pesawat itu berhasil dibeli melalui penggalangan dana rakyat, terutama penduduk Aceh, dirgantara nasional tidak memungkinkannya untuk beroperasi. Setelah Agresi Militer Kedua tahun 1948, militer Belanda menguasai berbagai pulau dan kota terutama Yogyakarta, ibukota Republik Indonesia. Pesawat yang baru dibeli itu dan sedang mengalami perbaikan (overhaul) di India terhalang untuk kembali ke tanah air. Keadaan itu menimbulkan gagasan untuk memanfaatkan pesawat itu melalui pembentukan sebuah perusahaan penerbangan sipil, yang dinamakan Indonesian Airways. Peluang operasional diperoleh dari pemerintah Burma. Hingga pembubarannya, perusahaan itu beroperasi di angkasa Burma (Myanmar). Jejak penerbangan sipil nasional berlanjut dengan pembentukan sebuah perusahaan patungan, antara Indonesia dan Negeri Belanda sebagai perwujudan kesepakatan Konperensi Meja Bundar. Perusahaan itu dinamakan Garuda Indonesian Airways. Kata Garuda berasal dari gagasan Presiden Sukarno. Selain itu, nama tersebut dimaksudkan untuk mengenang perusahaan penerbangan sipil nasional sebelumnya, yang dibubarkan pada tahun 1950 .

\section{KEBIJAKAN PENERBANGAN PERINTIS}

Pada UU Penerbangan nomor 83 Tahun 1958, penerbangan perintis belum tercantum dan diatur. UU itu lebih ditujukan untuk menggantikan produk hukum kolonial, selaras dengan semangat nasionalisasi dan Indonesianisasi, agar kedaulatan negara berlaku pula untuk dirgantara nasional, menyusul deklarasi negara kepulauan oleh Perdana Menteri Djuanda pada tanggal 13 Desember 1957. Tindakan itu tidak main- 
main, yang terbukti dengan upaya mempersatukan wilayah yang dinyatakan merdeka sesuai dengan UUD 1945 dalam perjuangan Irian Barat (kini Papua) pada tahun 1960. Perhatian terhadap persoalan itu tampak pada pembentukan MNA (Merpati Nusantara Airlines) tahun 1962.

Selanjutnya, pada majalah Angkasa² terbitan tahun 1975, tercantum keterangan bahwa

\begin{abstract}
"Pelayanan angkutan udara lainnya yang tidak kalah penting dan menyangkut pembinaan integrasi bangsa serta integritas wilayah adalah penerbangan perintis. Pelayanan angkutan ini tidak memberikan keuntungan, malahan dari perhitungan ekonomi lebih banyak menimbulkan kerugian. Namun, pelayanan jasa angkutan nasional tidak selalu bertumpu pada pertimbangan ekonomi. Pertimbangan politik dan juga budaya tidak dapat diabaikan. Hal yang tidak kalah penting adalah perwujudan komunikasi dan transportasi antar daerah di tanah air yang semakin lancar dengan adanya penerbangan perintis, termasuk antara pusat dan daerah. Selain itu, aspek strategi pertahanan tidak boleh dilupakan, karena melalui jaringan penerbangan ini, daerah-daerah perbatasan dan terpencil menjadi terawasi dan merupakan bagian dari komunikasi nasional."
\end{abstract}

Penerbangan perintis di dalam SK Menteri Perhubungan no. 126 tahun 1990 berbunyi sebagai berikut, yaitu "Penerbangan yang dilakukan secara regular dengan mendapat subsidi dari pemerintah untuk membuka daerah yang terisolasi dan berfungsi untuk pemerataan pembangunan". Dengan demikian, cirinya meliputi: Reguler, Subsidi Pemerintah, Daerah Terisolasi, dan Pemerataan Pembangunan. Subsidi diperoleh melalui aliran dari Departemen Perhubungan berupa subsidi bahan bakar dan subsidi operasi angkutan. Pada tahun 1992 terbit sebuah peraturan mengenai penerbangan, yang mengatur tentang penerbangan perintis. UU No. 15 Tahun 1992 itu menyatakan bahwa

\footnotetext{
"Pemerintah menyelenggarakan angkutan udara perintis untuk melayani jaringan dan rute penerbangan yang menghubungkan daerah-daerah terpencil dan pedalaman atau yang sukar terhubungi oleh moda transportasi lain. Guna membuka isolasi dan mengembangkan semua daerah dan pulau terpencil, angkutan udara perintis diselenggarakan oleh pemerintah dengan mengikutsertakan angkutan udara niaga nasional yang dapat diberi kemudahan tertentu."
}

Pada Undang-undang No. 1 tahun 2009 berbunyi “Angkutan Udara Perintis adalah kegiatan angkutan udara niaga dalam negeri yang melayani jaringan dan rute penerbangan untuk menghubungkan daerah terpencil dan tertinggal atau daerah yang belum terlayani oleh moda transportasi lain dan secara komersial belum menguntungkan." Pada UU itu, ciri-ciri penerbangan perintis meliputi angkutan udara niaga, domestik, daerah terpencil atau tertinggal dan belum menguntungkan. Komersialisasi dalam artian menciptakan keuntungan tidak menjadi prioritas dalam pelayanan penerbangan itu sehingga memerlukan subsidi.

Penerbangan perintis adalah angkutan udara yang sangat penting, dalam

\footnotetext{
${ }_{2}$ Angkasa no. 3, XXV. 1975, 7.
} 
menjangkau daerah terpencil atau yang tidak dapat dijangkau transportasi lainnya seperti darat dan laut, serta mempunyai kecepatan dan kelancaran dalam pelayanannya. Pada masa-masa awal Orde Baru enam daerah sentral penerbangan perintis ditetapkan. Daerah-daerah itu adalah Manado, Ambon, Kupang, Banjarmasin, Palembang, dan Medan. Daerah sentral Manado melayani jaringan penerbangan yang menghubungkan sejumlah kota di sekitarnya yang belum terjamah penerbangan komersil nasional. Kotakota itu adalah Naha, Melangguame, Kotamobagu, Luwuk, Poso, Gorontalo, Toli-toli, Ternate, Lowela, Pomala, Malili sampai Ujung Pandang (kini Makasar). Jaringan itu dilayani oleh dua pesawat jenis Twin Otter. Dengan jumlah pesawat yang sama dari Ambon penerbangan dilakukan menghubungkan kota-kota seperti Langgur, Saumlaki, Namlea, Dobo, Amuhai dan Mangole.

Selanjutnya, jaringan perintis dari Kupang meliputi sejumlah kota, yaitu Atambua, Maumere, Ruteng, Ende, Waingapu, Tabulaku, Sumba, Sumbawa Besar dan beberapa lainnya hingga mencapai Bali. Ada tiga pesawat jenis Twin Otter dalam jaringan itu. Jaringan penerbangan Banjarmasin meliputi beberapa kota seperti Muaratewe, Sampit, Pangkalanbun, Palangkaraya, Putussibau, Singkawang, Pontianak, Samarinda, Berauhingga menjangkau Natuna. Palembang merupakan sentra penerbangan perintis untuk kota-kota Pendopo, Tanjungkarang, Jambi, Bengkulu, Buluhtumbang (Belitung), Pekanbaru, Padang, hingga Gunung Sitoli di Nias. Sentra terakhir adalah Medan yang melayani penerbangan ke Penangsori di Sibolga, Seunagan di Meulaboh, Sabang dan Lhok Semawe. Sementara itu, di Irian Jaya (Papua) juga ada penerbangan perintis yang melibatkan 6 pesawat jenis Twin Otter. Kekurangan pesawat yang ada dipenuhi pemerintah dengan pembelian pesawat jenis itu dari Kanada (Angkasa no. 3, XXV, 1975, 7).

Pada UU Nomor 15 tentang penerbangan yang dikeluarkan pada tahun 1992 penerbangan perintis diatur dalam Pasal 38 yang terdiri atas dua butir. Butir pertama berbunyi bahwa "Pemerintah menyelenggarakan angkutan udara perintis untuk melayani jaringan dan rute penerbangan yang menghubungkan daerah-daerah terpencil dan pedalaman atau yang sukar terhubungi oleh moda transportasi lain." Di bagian penjelasannya terdapat tambahan penjelasan bahwa "guna membuka isolasi dan mengembangkan semua daerah dan pulau terpencil, angkutan udara perintis diselenggarakan oleh pemerintah dengan mengikutsertakan angkutan udara niaga nasional yang dapat diberi kemudhan tertentu." Butir kedua menyatakan bahwa "penyelenggaraan angkutan udara perintis sebagaimana dimaksud dalam ayat (1) diatur lebih lanjut dengan Peraturan Pemerintah."

Pada tahun 1994, frekuensi penerbangan perintis memperlihatkan gejala penurunan. Penyebabnya antara lain adalah persaingan dengan angkutan darat yang berkembang karena fasilitas perhubungan darat telah lebih baik, sebagian jalur perintis dipandang sudah mulai menguntungkan atau komersial, penurunan armada perintis disebabkan peralihan ke penerbangan komersial dan faktor kecelakaan yang mengurangi 
jumlah armadanya. Sebenarnya, penurunan itu justru memperlihatkan perbaikan pada moda transportasi lainnya, terutama angkutan darat dan keterbukaan daerah-daerah terpencil untuk jaringan perhubungan yang lebih lancar.

Pada tahun 1995 terbit Peraturan Pemerintah RI nomor 40 tentang angkutan udara yang dimaksudkan untuk melaksanakan ketentuan UU nomor 1 tahun 1992. Dalam peraturan itu tercantum rute perintis sebagai bagian dari rute dalam negeri (pasal 10 butir 3). Rute perintis (dalam pasal 11 butir 3) adalah rute yang menghubungkan daerah terpencil dan pedalaman serta daerah yang sukar terhubungi oleh moda tranportasi lain. Dalam penjelasannya dijelaskan bahwa

"yang dimaksud dengan rute perintis adalah rute yang menghubungkan daerah terpencil dan pedalaman atau daerah yang sukar terhubungi oleh moda transportasi lain, yang turut berfungsi dalam mendorong pertumbuhan dan pengembangan wilayah dalam rangka pemerataan pembangunan dan hasil-hasilnya, serta mewujudkan stabilitas pertahanan dan keamanan negara."

Kemudian pada tahun 2001 terbit suatu keputusan menteri Perhubungan nomor 11 yang menyebutkan evaluasi rute penerbangan dalam jangka waktu tiap 5 tahun.

Pada masa Reformasi, penerbangan perintis melayani angkutan udara di wilayahwilayah Aceh, Sumatera Utara, Sumatera Barat, Kalimantan Timur, Kalimantan Tengah, Nusa Tenggara Timur, Sulawesi Selatan, Sulawesi Barat, Sulawesi Tengah, Sulawesi Utara, Maluku, dan Maluku Utara. Di daerah Papua hampir seluruh perhubungan antar tempat dilakukan oleh penerbangan perintis. Hal itu disebabkan oleh keadaan alam, fasilitas perhubungan udara yang minim dan tingkat kebutuhan penerbangan masyarakat yang masih rendah. Jaringan perintis di Papua meliputi Nabire, Jayapura, Merauke, Timika, Manokwari dan Sorong.

Perusahaan-perusahaan penerbangan yang melayaninya adalah PT Sabang Merauke Raya Air Charter (SMAC), PT Riau Airlines (RA), PT Dirgantara Air Services (DAS), PT Merpati Nusantara Airlines dan PT Trigana Air Services (TAS) (Masrifah 2008: 1447). PT SMAC menerbangi lintasan perintis di Nanggroe Aceh Darussalam (NAD) dan Sumatera Utara. PT RA menghubungkan tempat-tempat di NAD yakni Takengon dan Sinabang. PT DAS beroperasi di Kalimantan Timur, Kalimantan Tengah, Sulawesi Selatan dan Sulawesi Barat. PT MNA melayani jalur-jalur perintis di Sulawesi Utara, Sulawesi Tengah, NTT, Maluku, Maluku Utara dan Papua. Lalu, PT TAS berpusat di Timika, Papua.

Pada tanggal 17 Desember 2007, Direktur Jenderal Perhubungan Udara mengeluarkan kebijakan tentang rute penerbangan perintis. Kebijakan itu ditetapkan dengan Keputusan bernomor SKEP/246/XII/2007 tentang Rute Penerbangan Perintis Tahun Anggaran 2008. Rute penerbangan perintis yang ditetapkan dalam Keputusan itu adalah penerbangan yang memperoleh subsidi dari pemerintah berupa operasi angkutan 
udara. Jaringan dan jalur penerbangan perintis itu adalah: ${ }^{3}$

1. Nanggroe Aceh Darussalam :

a. Sinabang-Meulaboh, $\mathrm{pp}^{4}$

b. Banda Aceh (- Meulaboh, pp, - Tapak Tuan, pp, - Blang Pidie, pp, - Takengon, pp, - Kutacane, pp)

c. Medan (- Tapak Tuan, pp, - Blang Pidie, pp, - Takengon, pp, - Kutacane, pp)

2. Sumatera Utara :

a. Gunung Sitoli - Pulau-pulau Batu, pp

b. Pulau-pulau Batu - Padang, pp

3. Sumatera Barat :

a. Padang - Rokot, pp

4. Kalimantan Timur :
a. Samarinda (- Data Dawai, pp, - Long Apung, pp)
b. Datadawai - Melak, pp
c. Tarakan - Long Bawan, pp
d. Long Bawan (- Long Layu, pp, - Malinau, pp)
e. Long Layu - Malinau, pp

5. Kalimantan Tengah :

a. Palangkaraya ( - Kuala Kurun, pp, - Kuala Pembuang, pp, - Buntok, pp)

6. Nusa Tenggara Timur :

a. Kupang (- Atambua, pp, - Bajawa, pp, - Sawu, pp)

7. Sulawesi Selatan :

a. Makassar (- Selayar, pp, - Tanatoraja, pp, - Bua, pp)

b. Bua-Masamba, pp

c. Masamba (- Seko, pp, - Rampi, pp)

8. Sulawesi Tengah :

a. Palu ( - Toli-Toli, pp, - Buol, pp, - Poso, pp)

9. Sulawesi Barat:

a. Makassar-Mamuju, pp

b. Mamuju - Balikpapan, pp

10. Sulawesi Utara:

a. Manado (- Naha, pp, - Melongguane, pp)

b. Naha - Melongguane, pp

11. Sulawesi Tenggara :

12. Maluku :

a. Kendari - Bau-bau, pp

a. Ambon ( - Namlea, pp, - Wahai, pp, - Kisar, pp, - Banda, pp)
b. Kisar - Saumiaki, pp
c. Banda - Amahai, pp
d. Saumiaki - Larat, pp
e. Langgur - Larat, pp

${ }^{3}$ http://julfan.wordpress.com/2008/01/18/departemen-perhubungan-tetapkan-rute-penerbangan-perintis/

4 . Pp adalah singkatan pulang-pergi. 
13. Maluku Utara :

14. Papua :

a. Ternate (- Labuha, pp, - Galela, pp, - Gebe, pp, - Mangole, pp)

b. Labuha - Sanana, pp

a. Nabire (-Sinak, pp, - Illaga, pp, - Illu, pp, - Fawi, pp, - Sugapa, pp)

b. Biak - Numfoor, pp

c. Jayapura (- Batom, pp, - Dabra,pp, - Oksbil, pp)

d. Wamena ( - Mulia, pp, - Karubaga, pp, - Bokondini, pp, - Tiom, pp, Dekai, pp, - Ellim, pp, - Apalapsili, pp)

e. Merauke (- Okaba, pp, - Kimaam, pp, - Bomakia, pp, - Kamur, pp, - Mindiptanah, pp)

f. Timika (- Beoga, pp, - Kokonau, pp, - Akimuga, pp, - Jila, pp, - Potowai, pp, Bilogai, pp, Jita, pp, - Illu, pp, - Dekai, pp)

15. Irian Jaya Barat :

g. Potowai - Kaimana, pp

a. Manokwari (- Anggi, pp, Kebar, pp, Merdey, pp, Wasior, pp)

b. Sorong (- Ayawasi, pp, - Inanwatan, pp, - Teminabuan, pp, Kambuaya, pp)

Pada undang-undang penerbangan terbaru, tahun 2009 pengaturan mengenai penerbangan perintis diperbaiki. UU No. 1/ Tahun 2009 tentang penerbangan mengatur bahwa "Angkutan Udara Perintis adalah kegiatan angkutan udara niaga dalam negeri yang melayani jaringan dan rute penerbangan untuk menghubungkan daerah terpencil dan tertinggal atau daerah yang belum terlayani oleh moda transportasi lain dan secara komersial belum menguntungkan." Pada Pasal 104 Ayat (1) tercantum bahwa angkutan udara perintis wajib diselenggarakan oleh Pemerintah, dan pelaksanaannya dilakukan oleh badan usaha angkutan udara niaga nasional berdasarkan perjanjian dengan Pemerintah. Pada Pasal 105 dinyatakan bahwa dalam keadaan tertentu angkutan udara perintis dapat dilakukan oleh pemegang izin kegiatan angkutan udara bukan niaga. Berikutnya pada ayat itu, Pemerintah merujuk pada pemerintah pusat karena pada ayat (2) dinyatakan bahwa dalam penyelenggaraan angkutan udara perintis sebagaimana dimaksud pada ayat (1), pemerintah daerah wajib menjamin tersedianya lahan, prasarana angkutan udara, keselamatan dan keamanan penerbangan, serta kompensasi lainnya. Sinergi kedua pemerintah itu sangat mendukung kelancaran pelayanan jasa tersebut.

Penerbangan perintis dilaksanakan secara terpadu dengan sektor lainnya berdasarkan pendekatan pembangunan wilayah, demikian pada Ayat (2) yang jelasjelas mengkaitkannya dengan perkembangan ekonomi daerah. Kemudian dalam Pasal 104 Ayat 4 disebutkan bahwa pemerintah akan melakukan peninjauan dan evaluasi menyangkut angkutan udara perintis setiap tahun. Ketentuan ini menyatakan bahwa kontrak penyelenggaraan penerbangan perintis diberikan hanya dalam jangka waktu satu tahun. Berkaitan dengan aturan itu, sejumlah perusahaan penerbangan yang menerjuni jasa perintis ini menyatakan bahwa pembukaan jalur penerbangan perintis memerlukan investasi yang tak sedikit, yang banyak diserap oleh pengadaan pesawat. Oleh karena 
itu, menurut beberapa studi, sebaiknya kontrak penerbangan perintis berjangka waktu sedikitnya sekitar 3 (tiga) tahun, mengingat rata-rata jangka pengembalian investasi (Pay Back Period) berada pada kisaran jangka waktu itu. Apabila jangka waktunya terlalu pendek, pihak yang merasakan kerugian adalah para operator penerbangan karena investasi modal yang telah ditanamkan belum bisa kembali dalam tenggang waktu itu. Beberapa operator menyebutkan bahwa untuk membuka penerbangan perintis, diperlukan investasi yang tak sedikit, khususnya untuk pengadaan pesawat.

Selanjutnya, dalam Pasal 105 disebutkan bahwa angkutan udara perintis dapat dilakukan oleh pemegang izin kegiatan angkutan udara bukan niaga. Peraturan itu membuka kesempatan yang sama untuk kedua jenis angkutan tersebut. Meskipun angkutan udara niaga dan bukan niaga tidak dibatasi untuk melaksanakan penerbangan perintis, tetap perlu menghindari terjadi duplikasi pelayanan penerbangan di satu rute, mengingat pada umumnya pasar rute perintis masih terbatas. Hal itu pernah dikeluhkan oleh pihak MNA, yang menyatakan berdasarkan pengalaman bahwa setelah membuka rute penerbangan perintis hingga ke pelosok-pelosok dan mempertaruhkan segalanya untuk membuka jalur baru tersebut, ternyata pemerintah juga memberikan jalur tersebut kepada maskapai lain yang ingin ikut menikmatinya. Ujung-ujungnya adalah keduanya malah terancam mengalami kerugian karena pasarnya memang belum mencukupi. Pemerintah sebaiknya mengevaluasi terlebih dahulu apakah pasar di suatu jalur perintis sudah berkembang atau belum. Jika belum, idealnya pemerintah memberikan kesempatan kepada operator perintis untuk menerbangkannya sesuai skala ekonomi adalah minimal 3 (tiga) tahun. Jika dalam evaluasi, pasar ternyata sudah mencukupi, jika perlu bahkan rute perintis tersebut diubah untuk dikembangkan lagi menjadi rute penerbangan komersial.

\section{SUMBANGSIH PENERBANGAN PERINTIS}

Dari suatu studi tentang penerbangan perintis tampak bahwa sumbangsih penerbangan perintis sangat signifikan terutama untuk daerah-daerah perbatasan dan tertinggal. Dalam penelitian Kadarmanto (1994: 82) dinyatakan:

\footnotetext{
“Semenjak diselenggarakannya penerbangan perintis tahun 1987-1992, maka dari hasil penelitian di atas, walaupun kecil, ada peningkatan pembukaan isolasi daerah perbatasan darat Kalimantan Timur. Pembukaan isolasi tersebut merangsang penduduk perbatasan untuk berhubungan dan bekerjasama dengan penduduk yang bertempat tinggal di daerah pantai yang lebih maju dan makmur, serta pusat pemerintahan. Karena terdapat jembatan udara yang menghubungkan daerah pusat pemerintahan dengan daerah perbatasan yang terpencil, maka melalui arus perpindahan orang, barang dan pos terdapat dampak-dampak perubahan terhadap penduduk daerah perbatasan, yaitu:

1. Rakyat daerah perbatasan merasa dipedulikan dan dibantu oleh pemerintah pusat.

2. Penataran P-4 oleh Tim BP-7 dapat diselenggarakan melalui ibukota kecamatan dengan penerbangan perintis.

3. Kepercayaan kepada pemerintah RI dapat ditegakkan karena melalui pemerataan pengiriman barang-barang yang meningkatkan kesejahteraan penduduk dapat terselenggara, atau setidak-
} 
tidaknya penduduk mempunyai jaminan angkutan barang dan orang karena rutinitas frekuensi penerbangan.

4. Negara kesatuan dapat terwujud melalui lancarnya angkutan berita pusat pemerintahan ke daerah-daerah terpencil atau sebaliknya. Sebagai misal terselenggaranya pemilu di daerah perbatasan dengan sukses. Demikian pula apabila ada hama penyakit yang berjangkit segera beritanya sampai di Samarinda melalui penerbangan perintis."

Keterbukaan angkutan di daerah pedalaman hingga ke kawasan perbatasan yang menjadi pintu gerbang ke negeri tetangga yang menjanjikan kesejahteraan ekonomi tidak melunturkan rasa cinta air. Kadarmanto (1994: 83) mendapati bahwa “Dari informasi yang didapat data bahwa kesetiaan penduduk Indonesia di daerah perbatasan timur. Walaupun mendapat pekerjaan di Malaysia Timur, masih tetap tinggi mereka berangkat dari Samarinda-Long Ampung, mendapat upah tinggi di wilayah Malaysia Timur, dan pada bulan-bulan tertentu kembali ke daerah perkotaan untuk menemui keluarganya. Jadi walaupun ekonomi didapatkan di negeri tetangga, mereka tetap merasa sebagai bangsa Indonesia."

Di Pulau Sumatra signifikansi penerbangan itu untuk perkembangan daerah tercatat pada suatu laporan perjalanan udara yang tercantum dalam majalah Angkasa. Catatan itu menceritakan bahwa

\begin{abstract}
"Potensi arus lalu litas di daerah Sumatera bagian Utara ini tampak akan meningkat terus dan mempunyai prospek yang baik. Namun sebagai imbangan lalu lintas itu perlu adanya sarana angkutan barang (kapal) yang mempunyai frekuensi yang lebih regular lagi, sehingga kegiatan ekonomi perdagangan antar pulau dan ekspor akan dapat berkembang dan tumbuh dengan wajar. Bukan itu saja, hal ini bahkan merupakan sarana penunjang yang amat penting artinya bagi kelancaran penerbangan perintis ke daerah-daerah yang terpencil di pedalaman. Di samping itu semua adalah potensi pariwisata yang berada di daerah-daerah seluruh Indonesia khususnya di daerah Sumatera utara ini perlu dibantu pengembangannya sehingga dengan demikian segala sesuatunya akan sejalan dengan apa yang menjadi program dari perusahaan-perusahaan penerbangan kita khususnya Merpati Nusantara baik bagi keperluan International Charter Operation, Domestic Trunk maupun penerbangan Perintis itu sendiri. Thelast but not the least lancarnya suatu jaring penerbangan rutin dan frekuensinya banyak tergantung pada keadaaan dan perkembangan setempat" (Angkasa no. 3, XXV. 1975, 13).
\end{abstract}

Selanjutnya, sumbangsih itu tampak pada pernyataan seorang kepala daerah. Pada tahun 1975 Gubernur Aceh Muzakir Warad mengungkapkan bahwa pembukaan penerbangan perintis sangat mendukung kegiatan pembangunan di daerahnya. Ia memberikan contoh bahwa pengiriman uang yang berjumlah hingga ratusan juta rupiah jika melalui darat mengandung risiko. Oleh karena itu, melalui jasa pelayanan penerbangan itu, pengiriman itu berlangsung lebih aman dan cepat.

Dari pembuktian terbalik, yakni pertumbuhan jumlah penerbangan yang mencerminkan kebutuhan, signifikansi dan relevansi pelayanan jasanya dapat dilihat dari keterangan berikut, bahwa 
"Untuk perkembangan angkutan penumpang perintis menunjukkan, dimana Sumatera pada tahun 2004/ 2005 pertumbuhannya menurun sebesar -27,3\%, tahun 2005/ 2006 meningkat sebesar $24 \%$, Kalimantan tahun 2005/ 2006 sebesar 22,94 \%, Papua tahun 2005/ 2006 sebesar 33,85, sedangkan rute penerbangan perintis dari tahun anggaran 2004 sampai dengan tahun 2007 juga menjadi bertambah, hal ini terlihat tahun 2004 terdapat 83 rute, tahun 2005 bertambah menjadi 90 rute dan tahun 2006 bertambah menjadi 94 rute "(Masrifah 2007, 1440).

Pertumbuhan tersebut tentu tidak boleh disikapi sebagai suatu bentuk atau bukti kemajuan pembangunan nasional karena idealnya penerbangan perintis semakin berkurang setiap tahunnya. Penurunan itu berbanding terbalik dengan pembukaan dan peningkatan penerbangan komersial. Penerbangan perintis bersadarkan pada penyediaan subsidi sehingga memakai anggaran belanja pemerintah pusat dan/ atau daerah (APBN dan APBD).

\section{PENUTUP}

Sejarah penerbangan sipil Indonesia adalah penerbangan perintis. Diawali di masa perjuangan mempertahankan kemerdekaan setelah proklamasi tanggal 17 Agustus 1945, penerbangan merupakan rintisan untuk menghadapi kekuatan udara kolonial. Di masa itu, perusahaan penerbangan sipil komersial dibentuk oleh sejumlah perwira Angkatan Udara Republik Indonesia yang beroperasi di angkasa Birma. Setelah itu, operasional perusahaan angkutan udara patungan yang didirikan setelah pengakuan kedaulatan merambah ke daerah-daerah yang belum dilayani oleh penerbangan, selain memulihkan jaringan yang telah ada.

Keadaan geografi Indonesia berupa kepulauan dan perekonomian serta kesejahteraan masyarakat di daerah menjadi latar belakang perintisan penerbangan perintis. "Jembatan udara" Kalimantan merupakan gagasan awal yang mendorong pencanangan kebijakan pelayanan angkutan udara itu.

Kebijakan penerbangan perintis menjadi nyata pada saat pendirian Perusahaan Negara Merpati Nusantara Airlines (MNA) tahun 1962. Latar belakang pendiriannya antara lain adalah sebagai pendamping GIA agar dapat memusatkan perhatian pada penerbangan komersial dalam dan luar negeri. Banyak kendala dan tantangan yang dihadapi oleh MNA dalam menerbangi jalur-jalur perintis. Perusahaan itu merupakan salah satu ujung tombak untuk membuka keterpencilan daerah dalam pelaksanaan pembangunan nasional. Namun, kesemuanya mampu diatasi oleh perusahaan itu dalam mengemban misi mulia tersebut.

Kemudian, jalur penerbangan perintis dilirik oleh perusahaan penerbangan lainnya. Era keterbukaan mendorong pertambahan jumlah perusahaan penerbangan di tanah air. Bersama MNA, mereka menembus kesulitan moda transportasi yang masih dirasakan di berbagai daerah yang masih tertinggal. Mereka berperanan besar dalam penciptaan dan pelestarian integrasi nasional terutama di daerah perbatasan. Selain itu, 
mereka juga memiliki sumbangsih penting dalam mendorong perekonomian daerah.

Berdasarkan keadaan dan pencapaian tersebut, kebijakan penerbangan perintis perlu dikembangkan lebih lanjut di masa mendatang. Kebutuhan layanan moda transportasi itu masih dirasakan setidaknya beberapa waktu ke depan selaras dengan proses pembangunan nasional yang sedang digalakan di seluruh daerah. Kondisi geografi sejumlah daerah memperlihatkan kebutuhan suatu moda angkutan yang efektif dan efisien yang mampu diberikan oleh penerbangan perintis. Namun, faktor subsidi seyogianya ditangani secara saksama agar tepat pada sasaran dan tidak menghamburkan biaya yang sia-sia. Idealnya, penerbangan perintis menghilang seraya pertumbuhan penerbangan komersial yang mencerminkan peningkatan daya beli masyarakat yang artinya terjadi perbaikan tingkat kesejahteraan di daerah.

\section{DAFTAR ACUAN}

\section{A. SUMBER PRIMER}

Lembaran Negara Republik Indonesia no. 35 1965. Pendirian Perusahaan Negara Perhubungan Udara Daerah dan Penerbangan Serba Guna "Merpati Nusantara".

Lembaran Negara Republik Indonesia no. 36 1965. Pendirian Perusahaan Negara Angkasa Pura Kemajoran.

Lembaran Negara Republik Indonesia no.91, 1971.Perusahaan Negara(PN) Perhubungan Udara Daerah dan Penerbangan Serba Guna "Merpati Nusantara" Perusahaan Perseroan Pengalihan Bentuk.

Redaksi (1975). "Mengikuti Penerbangan Perintis ke Sumatera." Angkasa, 3, XXV.

Rencana Kerja Departemen Perhubungan Tahun 2009 Jakarta: Sekretariat Jenderal Departemen Perhubungan, 2008.

Rencana Kerja (Renja) Departemen Perhubungan Tahun 2010. Jakarta: Departemen Perhubungan.

Rencana Pembangunan Jangka Panjang Departemen Perhubungan 2005--2025. Jakarta: Litbang Departemen Perhubungan, 2005.

Undang-Undang Republik Indonesia nomor 15 tahun 1992 Tentang Penerbangan.

Undang-Undang Republik Indonesia nomor 1 Tahun 2009 tentang Penerbangan.

\section{B . SUMBER SEKUNDER}

Dirgantara. "Masalah Pengangkutan di Indonesia Perlu Didirikan Beberapa Buah Lagi Perusahaan Angkutan Udara/ Penerbangan." Angkasa, XVII, Agustus. 1967.

Hakim, Chappy. Berdaulat di Udara Membangun Citra Penerbangan Nasional. Jakarta: Kompas. 2010.

Hutabarat, Arifin. Menggali Potensi Nasional Menurut M. Soeparno. Jakarta: Purel Mondial. 1991.

H.T. Perkembangan Penerbangan Sipil di Indonesia." Angkasa, Juli, XIII. 1962. 
Karundeng, Max. "Profil Penerbang Perintis Dulu Pegang MIG, Kini Twin Otter." Sinar Harapan, 13 Oktober. 1975.

Kristanto, Tri Agung. "Daerah Tertinggal Perbatasan, Jangan Dilupakan” Kompas, 26 Oktober. 2010.

Martono, K \& Usman Melayu. Perjanjian Angkutan Udara Indonesia. Tt: Mandar Maju. 1996.

Masrifah, Siti. "Pengkajian Kebutuhan Pesawat Udara Perintis dalam Melayani Penerbangan." Warta Penelitian Perhubungan. Vol. 20, no. 9. 2008.

"Merpati Nusantara Airlines Terbang Semakin Tinggi." Angkasa, no. 2/ VIII-XXXVII. 1987.

Nurjadin, Roesmin. “Sambutan Menteri/ Panglima Angkatan Udara RI pada Hari Penerbangan Nasional Tanggal 9 April." Angkasa, XVII. 1967.

Sastrosoenarto, Hartarto. Industrialisasi Serta Pembangunan Sektor Pertanian dan Jasa Menuju Visi Indonesia 2030. Jakarta: Gramedia Pustaka Utama. 2006.

. "Kearifan Budaya dalam Menanggulangi Bencana Alam"

Depok: Makalah Seminar Forum Budaya Dies Natalis ke-69 Fakultas Ilmu Pengetahuan Budaya Universitas Indonesia, 7 Desember. 2009.

S.D. Joesman. “Mengejar Road Map to Zero Accident.” Angkasa, 9, Juni, XVII. 2007.

Simanjuntak, P.N.H. Kabinet-kabinet Republik Indonesia dari Awal Kemerdekaan sampai Reformasi. Jakarta: Djambatan. 2003.

"Soal Hubungan antara Penerbangan Sipil dan Manusia Pemetjahannja terdapat pada Garuda Indonesia Airways." Angkasa, Mei, XII.I. 1962.

Soeharto. "Amanat Pedjabat Presiden RI Djenderal Soeharto pada Upatjara Memperingati Hari Penerbangan Nasional Tanggal 9 April 1967." Angkasa, XVII, April. 1967.

Soejatman, Cartono. "Kilas Balik Penerbangan Indonesia." Angkasa, 3, XIV, Desember. 2003.

Syaifullah M, C. Wahyu Haryo PS. "Penerbangan Perintis Gantungan Hidup Masyarakat Pedalaman." Kompas. Jumat 6 Maret. 2009.

Tim Penyusun. Sejarah Departemen Perhubungan: Dinamika Transportasi di Indonesia dari Masa ke Masa. Laporan Penelitian (tidak diterbitkan). Jakarta: Badan Penelitian dan Pengembangan Departemen Perhubungan RI. 2009.

\section{SUMBER SEKUNDER YANG TIDAK DITERBITKAN}

Ardani, Dani. Pembaruan Kebijakan Pola Jaringan Rute Penerbangan Di Wilayah Indonesia Bagian Timur. Depok: Tesis Magister Prencanaan dan Kebijakan Publik Fakultas Ekonomi Universitas Indonesia. 2002.

Kadarmanto, Ibnu. Kontribusi Penerbangan Perintis Terhadap Pemerataan Pembangunan di Daerah Perbatasan Darat Kalimantan Timur Dalam Rangka 
Meningkatkan Ketahanan Nasional. Jakarta: Tesis Program Pascasarjana Pengkajian Ketahanan Nasional Universitas Indonesia. 1994.

Munawar, Ahmad. Pengembangan Transportasi Yang Berkelanjutan. Yogyakarta: Pidato Pengukuhan Jabatan Guru Besar pada Fakultas Teknik Universitas Gajah Mada. 2007.

Sutarno. Sistem Penerbangan Nasional dalam Perspektif Ketahanan Nasional Studi Kasus Penerbangan Angkutan Udara. Jakarta: Tesis Magister Program Pascasarjana Pengkajian Ketahanan Nasional Universitas Indonesia. 2001. 



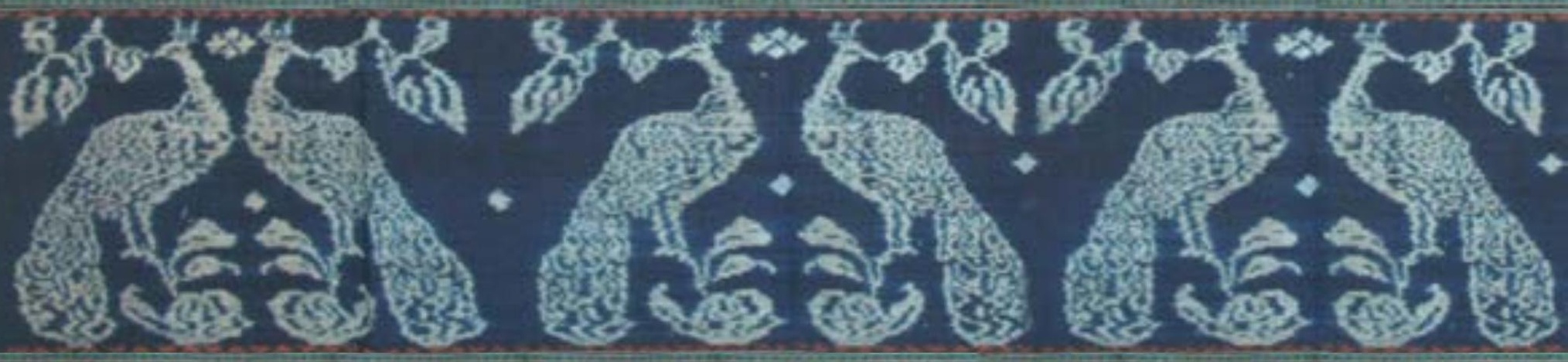

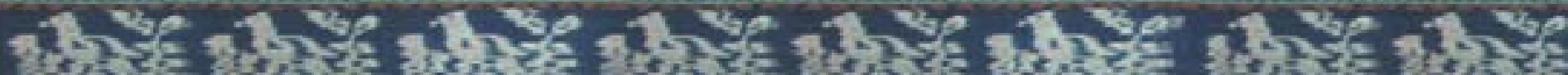

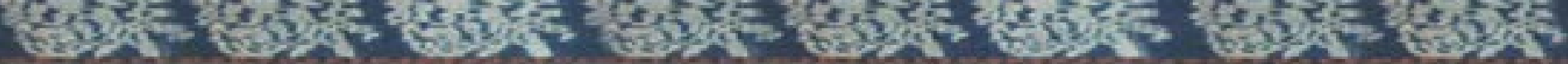

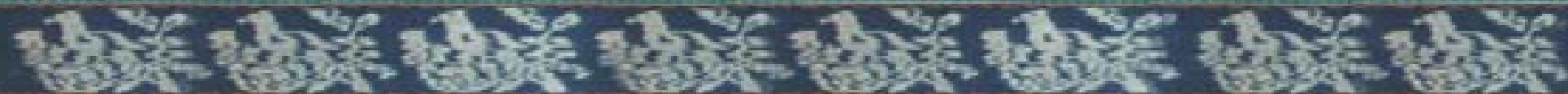

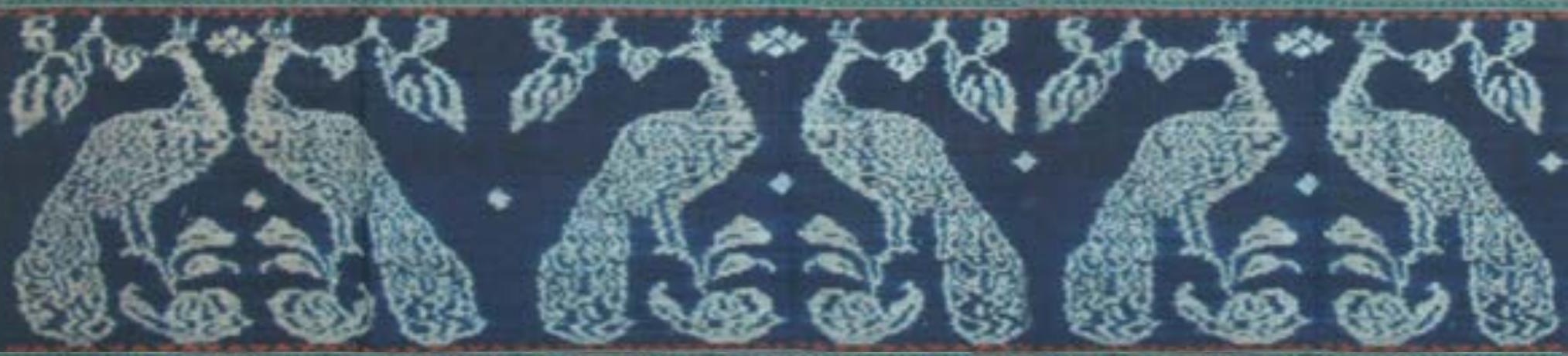

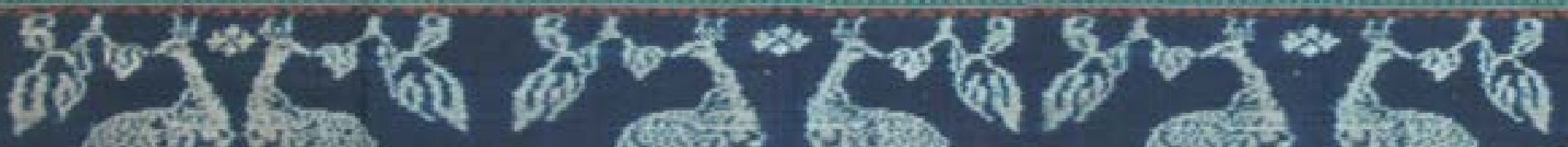

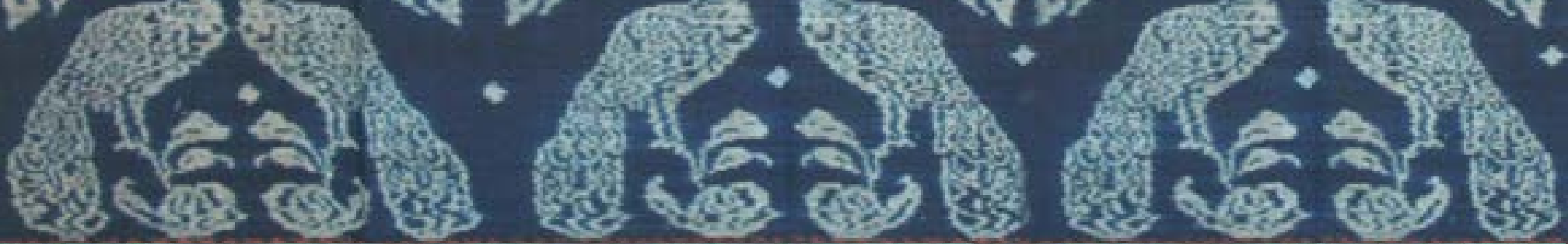

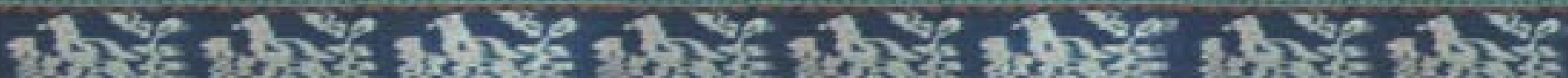

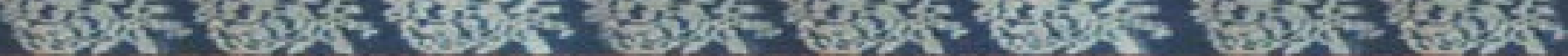

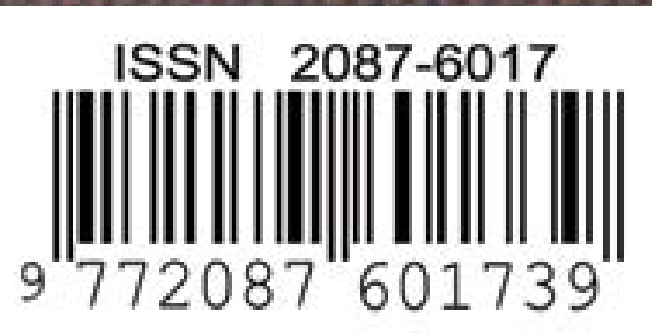

